\title{
MAPPING THE MAIN RISKS FOR OFFSHORE OPERATIONS IN THE PECHORA SEA
}

\author{
SLAVKO NESIC ${ }^{1}$, KONSTANTIN PIVOVAROV ${ }^{2}$, \\ VLADA STRELETSKAYA ${ }^{2} \&$ ANATOLY ZOLOTUKHIN ${ }^{2,3,4}$ \\ ${ }^{1}$ University of Belgrade, Serbia \\ ${ }^{2}$ Gubkin Russian State University (NRU) of Oil and Gas, Gubkin University, Russia \\ ${ }^{3}$ Northern Arctic Federal University, Arkhangelsk, Russia \\ ${ }^{4}$ Stavanger University, Norway
}

\begin{abstract}
The development of Prirazlomnoye oil field in the Pechora Sea was the first Russian oil and gas project in the Arctic. The environmental conditions are primarily function of water dynamics and ice cover for greatest part of the year. The marine environment in the Pechora Sea is characterized with many species including birds, fishes, benthic fauna and marine mammals. The food chains in the Arctic ecosystem are simple and very vulnerable to contamination. If pollutants harm one species, the whole food chain will be affected and can result in reducing a population of the specific species. In this paper, conceptual approach for environmental risk mapping is presented. The main pollution sources in the Pechora Sea were identified associated with possible risk and presented in the risk matrix. Qualitative analysis of possible risk events for water, air and soil pollution were analyzed and represented in appropriate bow-tie charts. Dangerous points in the Pechora Sea are mapped and their risk distribution are presented.
\end{abstract}

Keywords: Pechora Sea, offshore operations, risk mapping, marine environment, Arctic.

\section{INTRODUCTION}

Due to huge hydrocarbon reserves but at the same time being sensitive to anthropogenic impact, the uniqueness of the Arctic offshore fields is acknowledged all over the world. Despite high technological and financial risks, which call the profitability of Arctic projects into a question, the interest for the development of these regions is increasing. Currently, an intensive exploration process is going in Alaska (USA), offshore Greenland, in Norwegian and Barents (both Russia and Norway) seas and in Pechora Sea as well. Hydrocarbon resources are important to the Arctic countries and regions as "sources of income and resource rent" [1] and are the major economic driver in areas where activity is currently taking place [2]. But the importance of the field development in this area goes beyond the regional and national economies. Arctic can provide a new qualitative leap in the oil and gas industry through the adaptation to harsh operating conditions, increasing depth of drilling and a strong need for countries and companies to cooperate. Nowadays one of the most important area of the petroleum production in the Arctic is the Pechora Sea - an environmentally sensitive area, where petroleum industry is facing harsh weather conditions. Therefore, it is important to develop action plan and applications to support environmental protection, pollution prevention, as well as the tools to decrease probability and consequences of oil spills, such as environmental program, the environmental accounting system, environmental monitoring and environmental risk analysis. This paper describes environmental, technological and qualitative analysis of the main risks during offshore field development operations in the Pechora Sea. 


\section{OFFSHORE OPERATIONS IN THE PECHORA SEA}

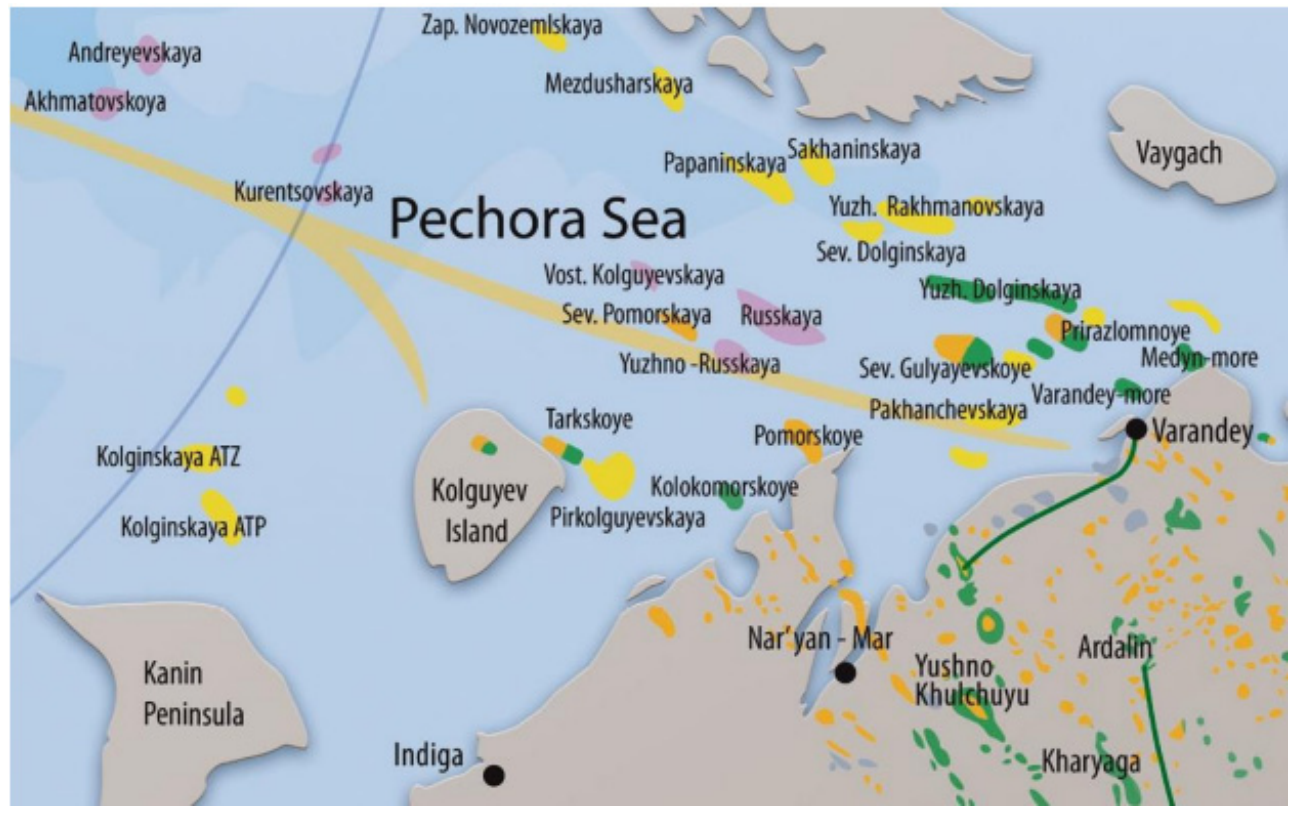

Figure 1: The structures and oilfields location in Pechora Sea.

The first seismic surveying in the Barents Sea began in the 1970s. The Pechora Sea is the southeastern part of the Barents Sea and total area is more than 81000 square kilometers, water volume is 4.38 thousand cubic meters, average depth is $6 \mathrm{~m}$, and maximum depth is $210 \mathrm{~m}$, where several oil and gas bearing structures were discovered. About 60 wells have been drilled in the area with very high discovery rate. The Pechora Sea has been claimed as one of the most perspective oil and gas region of the Russian Arctic. Six oil and gas fields have been discovered, i.e. Prirazlomnoye, Varandey-More, Medynskoye-More 2, Dolginskoye, North-Gulyaevskoe, Pomorskoye [3], [4].

The structures and oilfields location in Pechora Sea are shown in Fig. 1 [5]. The development of the Prirazlomnoye oil field was the first Russian oil and gas project in the Arctic. Oil production began in December 2013, in April 2014 Gazprom has shipped the first batch of the Arctic crude oil (ARCO) volume of 70000 tones, and in November 2015 was extracted the millionth ton of the ARCO. From 1989 till now 32 wells were drilled, 19 production wells operated with electrical submersible pumps (ESP), 12 injection wells and one disposal well. The whole system involves new technologies in completion, stimulation and control of the wells to increase the efficiency of production [6].

\section{PECHORA SEA MARINE ENVIRONMENT}

The most representative biological species of the Pechora Sea are birds, especially the water birds. There are 130 species, of which 50\% are water birds (Gavrilo et al., 2000). According to the surveys, the total number of the birds can reach 5.5 million, including 33.5 million ducks, 450-550 thousand of geese and 3545 thousand swans [7]. The most common birds in 
the Pechora Sea are: Eiders, Scoters, Long-tailed ducks, Sawbills, Unidentified dabbling ducks, Barnacle geese, Brent geese, Divers, Fulmars, Waders, Skuas, Common gulls, Lesser back-backed gulls, Glaucous gulls, Kittiwakes, Arctic terns, Guillemots, Raptors and owls, Bewick's Swan, Whooper Swan, Common Eider, King Eider, Steller's Eider, Long-tailed Duck, Northern Fulmar, Glaucous Gull, Black-legged Kittiwake, Ivory Gull, Little Auk, Brünnich's Guillemot, Black Guillemot [8]. The marine fish resources of the Pechora Sea include about 70 species [9], [10]. In addition, a lot of species migrate from the Kara Sea and Barents Sea to spend a winter under the ice of the Pechora Sea [11]. The most common fish species in the Pechora Sea are herring, navaga, rainbow smelt, Arctic cod, capelin, American plaice and Arctic flounder. The most common non-commercial fish species are slender eel blenny and Arctic staghorn sculpin. Non-commercial fish species as gobies and species from Liparidae and Zoarcidae increase a biodiversity in the Pechora Sea [12]. Marine mammals in the Pechora Sea include walruses, polar bears, seals and white wales. Walruses are mostly located in the shores and Kolguyev Island.

\section{POSSIBLE POLLUTANTS FROM THE OFFSHORE OPERATIONS IN THE PECHORA SEA}

In offshore drilling, the largest wastes disposed from platforms are drilling fluids and cuttings. Lighter fluids will stay in the water column while the heavier components tend to sink on the bottom [13]. Drilling fluids and cuttings are very complex mixture of liquid fluids (water, oil or other organic fluids), clays (barite), viscosifiers (polymers), emulsifiers (alkyl acrylate sulphonate, polyethylene oxide), $\mathrm{pH}$ control agents, deflocculants, shale control additives and rock particles. If that mixture is disposed to the sea, it can have a negative effect on benthic organisms [14], [15]. Disposed drilling cuttings in the North Sea have a total oil content between 10,000-600,000 mg/l [16]-[18]. Many studies show that biological degradation of hydrocarbon compounds is very slow and exist in just few millimeters and anaerobic degradation exists in $20-50 \mathrm{~cm}$ from the pile surface. Deeper parts of the piles in most cases are still unchanged are very resistant to chemical change [17]-[19]. Every disturbance of accumulated piles can cause erosion and uncover deep layers which can lead to leakage of possible contaminants [17].

Produced water is the largest byproduct generated during the oil and gas production and the main source of pollution at offshore platforms. The presence of water is identified in every stage of oilfield life, from the exploration, development, production and abandonment [20], [21]. Produced water represents the largest waste volume in oil and gas industry. The water-oil ratio (WOR) is increasing during the life cycle of the oilfield and the current global ratio is 3:1. In offshore facilities, the WOR is significantly higher [22]. Generally, the most of the onshore produced water treatment facilities are designed to remove suspended solids and dispersed oil compound to avoid disposal formation plugging. In offshore facilities, the common practice is discharging the treated produced water into the sea. To meet discharge quality and avoid toxicity effects on the marine environment, the content of hydrocarbons in producing water must be significantly lower [23].

Oil spills in the Arctic region are most dangerous types of pollution and it can have global consequences. Many reports and projects are prepared for spill response and management in the Arctic conditions [24]-[26]. There is a limited knowledge in environmental effects of oil spills in the Arctic zone mostly because there was not any large oil spill in this area [27], [28]. Problems with the oil spill detection must be overcome by using modern detection tools - sonars adapted for low visibility conditions [29]. Potential dangerous zones for the oil 
spills are Varandey terminal, Prirazlomnoye offshore platform and transportation routes. There are three transportation routes in the Pechora Sea called South, Central and North routes. Every route is passing through zones with different distributions of birds, fishes and marine mammals and present potential place for oil spills. These three routes form two separated surfaces in the Pechora and the Barents seas, which can have a negative influence on marine environment.

Ice breaking can have adverse effect on whales, mammals and fishes. Recent studies show that the whales can hear ice breaking from $35-78 \mathrm{~km}$ and tend to avoid this area for 1-2 days [30]-[32] and walruses can avoid ice breaking from $230 \mathrm{~m}$ to more than $1 \mathrm{~km}$ [33], [34] Movement of the animals caused by ice breaking requires additional energy consumption and displacement, which can result in competition and possible predation. Marine mammals are very sensitive to anthropogenic noise because sound is present in every part of their lives, from searching for food, navigation, reproduction and detection of predators or hazards [36].

Seabirds can be attracted by offshore facilities and icebreakers and exposed to contaminants especially during spawning period. Arctic routes are passing through several zones with high bird's population. Vulnerable bird species are gulls and sea ducks because their population is distributed on the shipping routes.

Due to low nutrition potential for marine life, every negative environmental impact such as oil spills, produced water discharges and ice breaking during the transport can affect food chains. Due to shallow waters, spilled oil or produced water discharge can reach the sea bottom, contaminate benthic fauna and accumulate in the sediments.

Walruses and seals are mostly located in the shores and Kolguyev Island. Polar bears are located north from the Prirazlomnoye platform and belugas in the middle of the Pechora Sea. They are distributed on the main Arctic routes except the North one.

\section{QUALITATIVE ANALYSIS OF the MAIN RISKS DURING OFFSHORE OPERATIONS}

In this section, a qualitative analysis of the main risks in offshore operations is performed. Such tools as risk matrix, bow-tie diagram, development of qualitative acceptance criteria and analysis of pollution risk sources were used here.

\subsection{Risk matrix}

The risk value in this study is evaluated as follows:

$$
\text { Risk value }=\text { Probability rating } \mathbf{x} \text { Impact score }
$$

A typical example of the risk matrix is shown in Table1.

Qualitative acceptance criteria used in this study are defined as follows:

$1-4=$ Low risk (acceptable risk)

5-9 = Medium risk (reasonably practicable)

10-16 $=$ High risk (not acceptable risk)

20-25 = Very high risk (not acceptable risk) 
Table 1: Risk matrix example.

\begin{tabular}{|c|c|c|c|c|c|c|}
\hline & & \multicolumn{5}{|c|}{ Probability rating (likelihood) } \\
\hline \multicolumn{2}{|c|}{ Environmental impact } & $\begin{array}{c}\text { Very } \\
\text { unlikely }\end{array}$ & Unlikely & Possible & Likely & Very likely \\
\hline & & & & & & \\
\hline Negligible & 1 & 1 (Low) & 2 (Low) & 3 (Low) & 4 (Low) & 5 (Medium) \\
\hline Slight & 2 & 2 (Low) & 4 (Low) & 6 (Medium) & 8 (Medium) & 10 (High) \\
\hline Moderate & 3 & 3 (Low) & 6 (Medium) & 9 (Medium) & 12 (High) & 15 (High) \\
\hline High & 4 & 4 (Low) & 8 (Medium) & 12 (High) & 16 (High) & $\begin{array}{c}20 \text { (Very } \\
\text { High) }\end{array}$ \\
\hline Very high & 5 & 5 (Medium) & 10 (High) & 15 (High) & $\begin{array}{c}20 \text { (Very } \\
\text { High) }\end{array}$ & $\begin{array}{c}25 \text { (Very } \\
\text { High) }\end{array}$ \\
\hline
\end{tabular}

Possible risk events for water pollution considered in this study are:

1. Platform wellhead leaking

2. Drilling cuttings discharge

3. Collapse of the riser or coiled-tubing

4. Deck drainage

5. Collapse of subsea oil pipeline

6. Sanitary and domestic wastes

7. Storage tanks leaking

8. Produced water discharge

9. Platform offloading leaking

10. Produced sand

11. Tanker (vessel) leaking

12. Fuel spill

13. Tanker (vessel) collision

14. Fracturing fluids spills

15. Terminal leaking

16. Oil spill

17. Terminal pipeline damage

18. Chemical discharges during construction

19. Drilling muds discharge

20. Damage of subsea pipelines by falling objects (anchors) and icebergs

Possible risk events for air pollution considered in this study are:

1. Natural gas flaring

2. Aerosol particles of the unburned fuel

3. Turbine (engine) exhaust

4. LNG tanker damage

5. Evaporation or venting of hydrocarbons during different operations

6. Damage of subsea pipelines by falling objects (anchors) and icebergs

7. Fuel exhaust (chopper, tanker, vessels) 
Risk matrix for considered risks of water pollution is shown in Table 2.

Table 2: Risk matrix for considered risks of water pollution.

\begin{tabular}{|c|c|c|c|c|c|c|}
\hline \multirow{2}{*}{\multicolumn{2}{|c|}{$\begin{array}{c}\text { Environmental } \\
\text { impact }\end{array}$}} & \multicolumn{5}{|c|}{ Probability rating (likelihood) } \\
\hline & & \multirow{2}{*}{$\begin{array}{c}\begin{array}{c}\text { Very } \\
\text { unlikely }\end{array} \\
1\end{array}$} & \multirow{2}{*}{$\begin{array}{c}\text { Unlikely } \\
2\end{array}$} & \multirow{2}{*}{$\begin{array}{c}\text { Possible } \\
3\end{array}$} & \multirow{2}{*}{$\begin{array}{c}\text { Likely } \\
4 \\
13\end{array}$} & \multirow{2}{*}{ 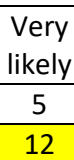 } \\
\hline Negligible & 1 & & & & & \\
\hline Slight & 2 & & & & 19 & \\
\hline Moderate & 3 & & & $\begin{array}{c}10,11 \\
15\end{array}$ & & \\
\hline High & 4 & $4,5,6,8$ & & $\begin{array}{l}1,14 \\
16,17\end{array}$ & & \\
\hline Very high & 5 & 7,9 & 2,3 & 18,20 & & \\
\hline
\end{tabular}

Risk matrix for considered risks of air pollution is show in Table 3.

Table 3: Risk matrix for considered risks of air pollution

\begin{tabular}{|c|c|c|c|c|c|c|}
\hline \multirow{3}{*}{\multicolumn{2}{|c|}{$\begin{array}{l}\text { Environmental } \\
\text { impact }\end{array}$}} & \multicolumn{5}{|c|}{ Probability rating (likelihood) } \\
\hline & & \multirow{3}{*}{$\begin{array}{c}\text { Very } \\
\text { unlikely }\end{array}$} & \multirow{3}{*}{$\begin{array}{c}\text { Unlikely } \\
2 \\
\end{array}$} & \multirow{3}{*}{$\begin{array}{c}\text { Possible } \\
3\end{array}$} & \multirow{3}{*}{$\begin{array}{c}\text { Likely } \\
\\
4 \\
3 \\
\end{array}$} & \multirow{3}{*}{$\begin{array}{c}\text { Very } \\
\text { likely } \\
5 \\
2 \\
\end{array}$} \\
\hline & & & & & & \\
\hline Negligible & 1 & & & & & \\
\hline Slight & 2 & & & 5 & 4 & 1 \\
\hline Moderate & 3 & & & & & \\
\hline High & 4 & & & 6 & & \\
\hline Very high & 5 & & 7 & & & \\
\hline
\end{tabular}

Possible risk events for soil pollution considered in this study are:

1. Platform wellhead leaking

2. Terminal pipeline damage

3. Collapse of the riser or coiled-tubing

4. Drilling cuttings discharge

5. Collapse of subsea oil pipeline

6. Produced water discharge

7. Storage tanks leaking

8. Fuel spill

9. Platform offloading leaking

10. Fracturing fluids spills

11. Tanker (vessel) leaking 
12. Oil spill

13. Tanker (vessel) collision

14. Damage of subsea pipelines by falling objects (anchors) and icebergs

15. Terminal leaking

16. Terminal pipeline damage

Risk matrix for considered risks of soil pollution is show in table 4. Cumulative risk events for water, air and soil pollution are presented in table 5. As follows from table 5, most of the classified risk events (17), belong to the intersecting cells with High/Very high environmental impact rows and Unlikely/Possible probability. columns, of which nearly half of the events (8), belong to the cell "High environmental impact+Possible probability".

Table 4: Risk matrix for considered risks of soil pollution.

\begin{tabular}{|c|c|c|c|c|c|c|}
\hline \multirow{2}{*}{} & \multicolumn{5}{|c|}{ Probability rating (likelihood) } \\
\cline { 2 - 8 } Environmental impact $\begin{array}{c}\text { Very } \\
\text { unlikely }\end{array}$ & Unlikely & Possible & Likely & Very likely \\
\cline { 3 - 8 } & & 1 & 2 & 3 & 4 & 5 \\
\hline Negligible & 1 & & & & & \\
\hline Slight & 2 & & & & & \\
\hline Moderate & 3 & & $5,6,8$ & & & \\
\hline High & 4 & 4 & 1,13 & $10,11,12$ & & \\
\hline Very high & 5 & $2,3,7,9$ & & 14,15 & & \\
\hline
\end{tabular}

Table 5: A cumulative risk events for water, air and soil pollution.

\begin{tabular}{|c|c|c|c|c|c|c|}
\hline \multirow{2}{*}{$\begin{array}{c}\text { Environmental } \\
\text { impact }\end{array}$} & $\begin{array}{c}\text { Pery } \\
\text { unlikely }\end{array}$ & Unlikely & Possible & Likely & $\begin{array}{c}\text { Very } \\
\text { likely }\end{array}$ \\
\cline { 2 - 7 } & & 1 & 2 & 3 & 4 & 5 \\
\hline Negligible & 1 & & & & 2 & 2 \\
\hline Slight & 2 & & & 1 & 2 & 1 \\
\hline Moderate & 3 & & 3 & 3 & & \\
\hline High & 4 & 5 & 2 & 8 & & \\
\hline Very high & 5 & 6 & 3 & 4 & & \\
\hline
\end{tabular}


5.2 Bow-tie diagrams for water, air and soil pollution

Bow-tie diagrams present a simple and useful tool for displaying causal relationship between potential causes, methods of prevention, methods of mitigation and consequences of potential incident scenarios. In this article, bow-tie diagrams for water, air and soil pollution are presented.

Bow-tie diagram for water pollution in oil platform is shown on Fig. 2.

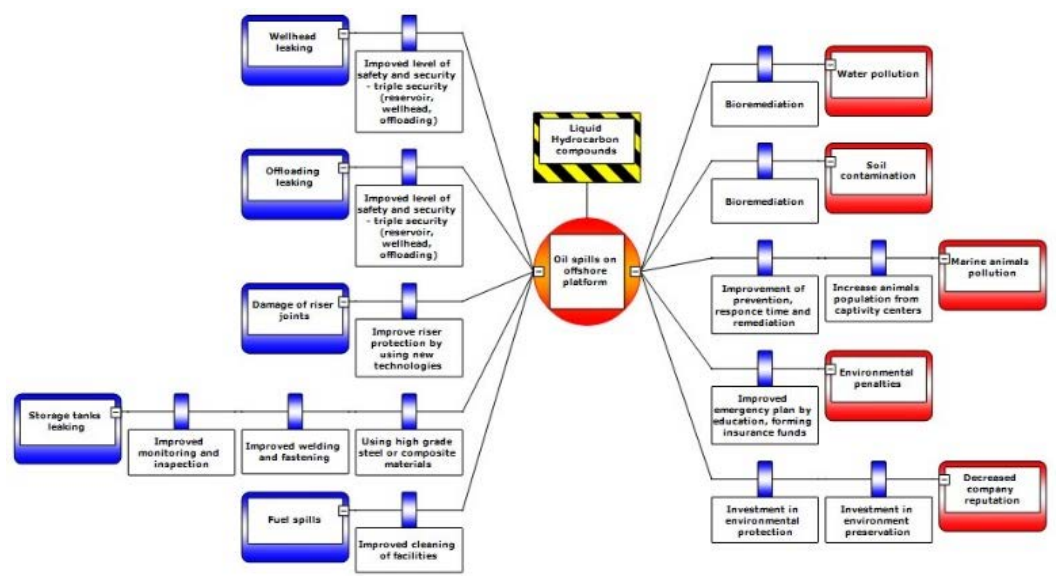

Figure 2: Bow-tie diagram for water pollution in the oil platform.

Bow-tie diagram for air pollution is shown on Fig. 3.

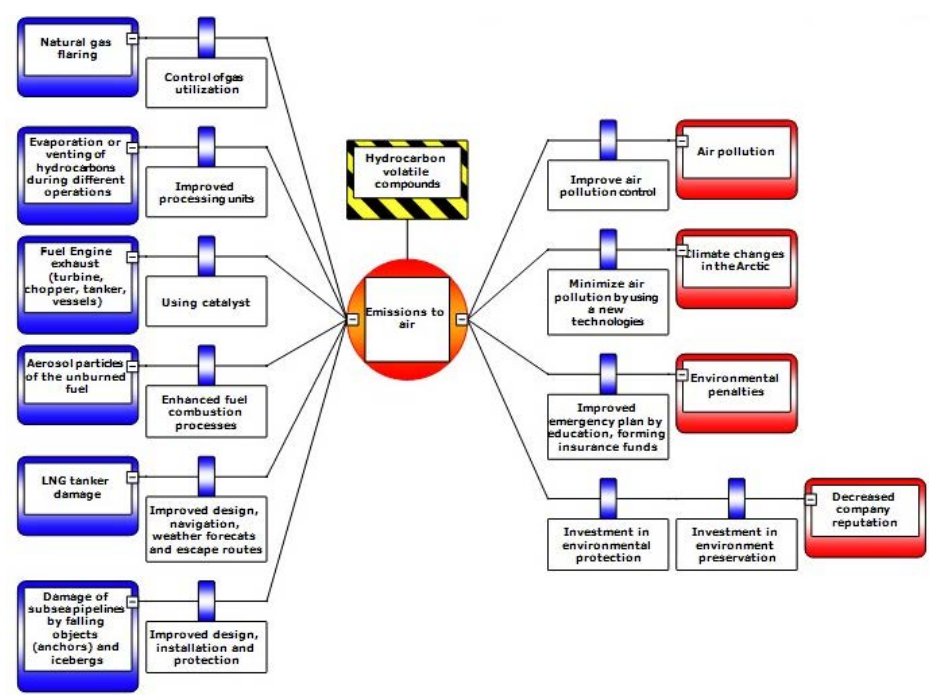

Figure 3: Bow-tie diagram for air pollution. 


\section{MAPPING RISK OF POTENTIAL POLLUTION IN THE PECHORA SEA}

For the purpose of potential pollution's mapping the Pechora Sea was divided into several zones. Those areas were studied and assessed by using multi-criterion approach (water, soil and air pollution risks). The methodology of mapping was based on the fuzzy logic theory [37] and its implementation for the technological accessibility assessment of the Arctic seas [38]. Potential pollution risk mapping was made here for the case of the Prirazlomnoye oil field development and the routes of oil transportation from this field. For simplicity of the analysis other fields in the Pechora Sea were not considered in this study since their addition would change the map and make it more complex. As follows from this Figure, the oil field development and the oil transport may affect quite a number of zones in the Pechora Sea, and their impact may spread on the entire area of the sea. Analysis of the risk caused by air, water and soil pollution was done for every zone of the sea. Using fuzzy logic and methodology developed in [38], we split the whole range of impact into eight different classes, where the $1^{\text {st }}$ class has the lowest and the $8^{\text {th }}$ - the highest risk factor (see Fig. 4).

By combining air, water and soil types of pollution risks using fuzzy logic it is possible to build one aggregate pollution risk map shown in Fig. 5.

As follows from the figure, the highest risk factor is near the Prirazlomnoye oil field and the transportation routes. It is important to note here that this map illustrates only risk associated with air, water and oil pollution and does not account for the weather and ice conditions.

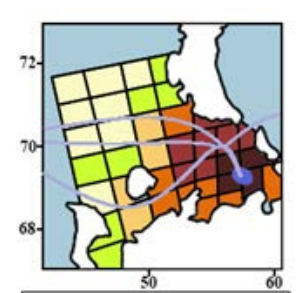

a) Air pollution risks

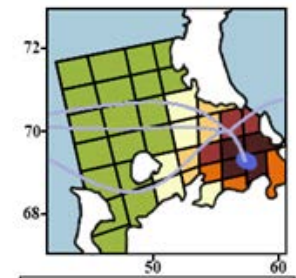

b) Water pollution risks

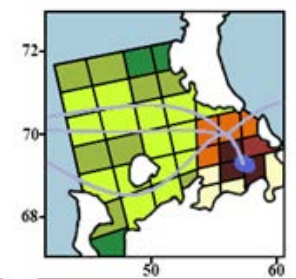

c) Soil pollution risks

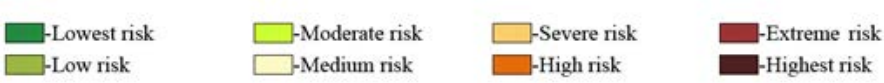

Figure 4: Air, water and pollution risks in the Pechora Sea.

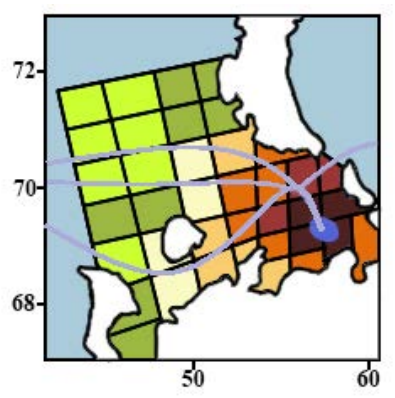

Figure 5: Map of pollution risk caused by oil production from the Prirazlomnoye oil field and the oil transportation routes. 


\section{CONCLUSIONS}

Petroleum production in the Arctic is facing harsh weather conditions and heavy cost compared with other petroleum provinces. Serious threats compose Arctic ecosystem vulnerability, such as risk of oil spills and difficulties in spill response in ice-infested waters. The challenges will be even higher in the future, as production is expected to move further offshore and to more remote areas, where industry faces the lack of infrastructure, rescue services and transportation options.

Minimization of different kinds of the environmental impact can be achieved by reducing emission to atmospheric air as well as discharges to water and waste disposed into the sea. It is important to note that treatment of produced water takes special place, not only due to ecological reasons, but also because of being a major component of the oil and gas production cost.

\section{REFERENCES}

[1] Glomsrød, S. \& Aslaksen, I., eds, The Economy of the North - 2008. Available at: https://www.ssb.no/a/publikasjoner/pdf/sa112_en/sa112_en.pdf.

[2] Arctic Oil and Gas 2007, Report of AMAP. 2007. Available at: https://www.amap.no/ documents/doc/arctic-oil-and-gas-2007/71.

[3] Moe, A., Russian and Norwegian petroleum strategies in the Barents Sea, Arctic Review on Law and Politics, 1(2), pp. 225-248, 2010.

[4] Korchagin, I.N., Levashov, S.P., Yakymchuk, N.A., Solovyov, V.D., Bakhmutov, V.G. \& Bozhezha, D.N., Some results of new geoelectric and "satellite" technologies using for the hydrocarbon resources prospecting at the continental margins of the West Antarctic and other regions. Electronic scientific journal Oil and Gas Business, 1 pp. 262-278, 2012.

[5] Boiko, A.R., Offshore Ice-resistant Fixed Platform for the Dolginskoye field in the Pechora Sea, Master's Thesis, University of Stavanger, Faculty of Science and Technology, 2014.

[6] Morozov, O.N., Andriyanov, M.A., Koloda, A.V., Shpakov, A.A., Melnikov, S.I. \& Simakov, A.E., Horizontal Wells Permanent Downhole Monitoring to Optimize Carbonate Reservoir Development. Society of Petroleum Engineers, 2016. Doi:10.2118/181900-MS.

[7] Mineyev, Y.N., Ansenifonnes of North-Eastem tundras (distribution, population dynamics, protection), Abstracts, Thes. Dr. Sci. Dissertation, Moscow 54. 1999 (In Russian).

[8] Strom, H., Isaksson, K. \& Golovkin, A.N., Seabird and wildfowl surveys in the Pechora Sea during august, the joint Norwegian-Russian commission on environmental cooperation, Report No. 2-2000. 1998.

[9] Gavrilo, M.V., Ekker, M., Strom, H. \& Vongraven, D., The Pechora Sea region - a unique pristine environment at risk of oil and gas development, SPE 61498. 2000.

[10] Andriyashev, A.P. \& Chemova, N.V. Annotated list of fish forms and fishes of Arctic Seas and adjacent waters, Problems of Ichthyology, 34(4), p. 435. (In Russian), 1994.

[11] Borkin, I.V., Breeding and early stages of the Polar cod Borogadus saida (Zep.) of the Barents Sea, Abstr., PhD thesis, Moscow 21, 1990. (In Russian).

[12] Semushin, A.V., Sherstkov, V.S \& Rukhlova, V.A., Diversity of Fish Species in the Trawl Catches in the South-eastern Barents Sea in 1980-2008. Journal of Ichthyology, 51(9), pp. 717-737, 2011. 
[13] Neff, J.M., Composition, environmental fates, and biological effects of water based drilling muds and cuttings discharged to the marine environment, A Synthesis and Annotated Bibliography, Prepared for Petroleum Environmental Research Forum (PERF) and American Petroleum Institute, 2005. Available at: http://www.perf.org/ images/Archive_Drilling_Mud.pdf.

[14] Durgut, I., Rye, H., Reed, M., Smit, M. G. \& Ditlevsen, M. K. Dynamic modelling of environmental risk associated with drilling discharges to marine sediments. Marine Pollution Bulletin, 99(1), (2), pp. 240-249, 2015, doi:10.1016/ j.marpolbul.2015.07.019.

[15] Davies, J.M. \& Kingston, P.F., Sources of environmental disturbance associated with offshore oil and gas developments. In: Cairns, W.J., ed., North Sea Oil and the Environment: Developing Oil and Gas Resources, Environmental Impacts and Responses. University Press Cambridge, 1992.

[16] Bell, N., Smith, M. \& Manning, A., Determination of the Physical Characteristics of Cuttings Piles, Using Existing Survey Data and Drilling Information. R\&D Programme 1.1 A report for the UKOOA Drill Cuttings Joint Industry Project, Report No. Chorda/UKO012/1999, 2000. Available at: http://citeseerx.ist.psu.edu/ viewdoc/download?doi=10.1.1.469.9589\&rep=rep1\&type=pdf.

[17] Bakke, T., Klungsøyr, J. \& Sanni, S., Environmental impacts of produced water and drilling waste discharges from the Norwegian offshore petroleum industry. Marine Environmental Research, 92, pp. 154-169, 2013, doi:10.1016/ j.marenvres.2013.09.012.

[18] Breuer, E., Stevenson, A., Howe, J., Carroll, J. \& Shimmield, G., Drill cutting accumulations in the Northern and Central North Sea: a review of environmental interactions and chemical fate. Marine Pollution Bulletin, 48(1), (2), pp. 12-25, 2004, doi:10.1016/j.marpolbul.2003.08.009.

[19] Hartley, J. \& Watson, T., Investigation of A North Sea Oil Platform Drill Cuttings Pile. Offshore Technology Conference, 1993, doi:10.4043/7341-ms

[20] Veil, J.A. Puder, M.G., Elcock, D. \& Redweik, R.J. A white paper describing produced water from production of crude oil, natural gas, and coal bed methane, 2004. Doi:10.2172/821666.

[21] Khatib, Z. \& Verbeek, P., Water to Value-Produced Water Management for Sustainable Field Development of Mature and Green Fields. Journal of Petroleum Technology, 55(1), pp. 26-28, 2003, doi:10.2118/0103-0026-jpt.

[22] Whalen, T., The Challenges of Reusing Produced Water. Journal of Petroleum Technology, 64(11), pp. 18-20, 2012, doi:10.2118/1112-0018-jpt.

[23] Hussain, A., Minier-Matar, J., Janson, A., Gharfeh, S. \& Adham, S. Advanced Technologies for Produced Water Treatment and Reuse. International Petroleum Technology Conference, 2014, doi:10.2523/iptc-17394-ms.

[24] EPA, Characteristics of Response Strategies: A Guide for Spill Response Planning in Marine Environments, A joint publication of the American Petroleum Institute National Oceanic and Atmospheric Administration U.S. Coast Guard U.S. Environmental Protection Agency Seattle, Washington June 2001 Available at: https://docs.lib.noaa.gov/noaa_documents/NOS/ORR/910_response.pdf.

[25] Potter, S., Buist, I., Trudel, K., Dickins, D. \& Owens, E., Spill Response in the Arctic Offshore. Prepared for the American Petroleum Institute and the Joint Industry Programme on Oil Spill Recovery in Ice February 2012. Available at: 
http://www.api.org/ /media/Files/EHS/Clean_Water/Oil_Spill_Prevention/SpillResponse-in-the-Arctic-Offshore.ashx.

[26] EPPR, Emergency Prevention, Preparedness and Response. Field Guide for Oil Spill Response in Arctic Waters 2017. Available at: http://www.arctic-council.org/eppr/wpcontent/uploads/2016/11/2016 1124 EPPR Field Guide for Oil Arctic 2016.pdf

[27] Rusten, M., Aarnes, Ø. \& Brude O. W., Arctic Risk Picture - Management of Safety and Environmental Risk, Offshore Mediterranean Conference and Exhibition, 25-27 Mar. 2015, Ravenna, Italy.

[28] Mullin, J. V., A Joint Industry Programme to Improve Oil Spill Response in the Arctic. Arctic Technology Conference, 2016, doi:10.4043/27431-ms.

[29] Eriksen, P.K., Oil Spill Detection and Mapping tool in Low Visibility and Arctic Ice Settings. OTC Arctic Technology Conference, 2012, doi:10.4043/23806-ms.

[30] Erbe, C. \& Farmer, D.M., Zones of impact around icebreakers affecting beluga whales in the Beaufort Sea. The Journal of the Acoustical Society of America, 108(3), p. 1332, 2000, doi:10.1121/1.1288938.

[31] Wilson, S.C., Trukhanova, I., Crawford, I., Dolgova, E., Dmitrieva, L. \& Goodman S.J., Assessment and mitigation of the impacts from icebreaking vessels on icebreeding pinnipeds in the Holarctic. 2014. Available at: http://www.sealresearch.org/attachments/article/581/SW_mmh8_Shipping_impact_ic e-breeding\%20seals_text.pdf

[32] Cosens, S.E. \& Dueck, L.P., Icebreaker Noise in Lancaster Sound, N.w.t., Canada: Implications for Marine Mammal Behaviour. Marine Mammal Science, 9(3), pp. 285300, 1993, doi:10.1111/j.1748-7692.1993.tb00456.x.

[33] Boltunov, A.N, Belikov, S.E., Gorbunov, Y.A., Menis, D.T. \& Semenova, V.S., The Atlantic Walrus of the southeastern Barents Sea and adjacent regions: review of the present-day status. WWF-Russia, Marine Mammal Council, Moscow. 2010. Available at: https://www.wwf.ru/resources/publ/book/eng/458.

[34] Brueggemann, J.J., Volsen, D.P. Grotefendt, R.A. Green, G.A., Burns J.J. \& Klungblad, D.K., 1991. 1990 Walrus monitoring program: The Popcorn, Burger and Crackerjack Prospects in the Chukchi Sea. Final report for Shell Western E\&P Inc, 1991. Available at: http:/www.arlis.org/docs/vol1/E/Walrus/US/ Brueggeman.etal.1991.ShellWalrusMonitoing1990.pdf.

[35] Stewart, R.E.A., Lesage, V., Lawson, J.W., Cleator, H. \& Martin, K.A. Science Technical Review of the draft Environmental Impact Statement (EIS) for Baffinland's Mary River Project. DFO Can. Sci. Advis. Sec. Res. Doc. 2011/086. 2015 Available at: http://waves-vagues.dfo-mpo.gc.ca/Library/346307.pdf.

[36] Weilgart, L.S., A brief review of known effects of noise on marine mammals. Int. J. Comp. Psychol. 20(2),159-168, 2007.

[37] Zade L.A., Fuzzy sets, Information and Control, 8(3), pp. 338-353, 1965.

[38] Pivovarov K.N. \& Zolotukhin A.B. Review of clusterization and ranking methods for technological accessibility assessment of the Arctic seas illustrated by the Barents Sea case study. Oil Industry journal, 7, pp. 64-67, 2017. 